\title{
Disruption by Interferon- $\alpha$ of an Autocrine Interleukin-6 Growth Loop in IL-6-dependent U266 Myeloma Cells by Homologous and Heterologous Down-regulation of the IL-6 Receptor $\alpha$ - and $\beta$-Chains
}

\author{
Michael Schwabe, * Anna T. Brini, \$" Maria Carla Bosco, ${ }^{\ddagger}$ Francesca Rubboli, " Masayuki Egawa, * Jian Zhao, * \\ Gerald L. Princler, * and Hsiang-fu Kung * \\ * Laboratory of Biochemical Physiology and ${ }^{\ddagger}$ Laboratory of Experimental Immunology, Biological Response Modifiers Program, \\ National Cancer Institute-Frederick Cancer Research and Development Center, Frederick, Maryland 21701; ${ }^{8}$ Molecular Allergy and \\ Immunology Section, National Institutes of Allergy and Infectious Diseases, Rockville, Maryland 20852; and "Dipartimento di \\ Farmacologia, Chemioterapia e Tossicologia Medica, Universita di Milano, 20129 Milano, Italy
}

\begin{abstract}
IL-6 is an autocrine growth factor for U266 myeloma cells and their growth is inhibited by IFN- $\alpha$ or IL-6 mAb. We asked, therefore, whether IFN- $\alpha$-induced growth inhibition involved IL-6. IFN- $\alpha$ and mAb against IL-6, the IL-6R $\alpha$ (gp80) or $\beta$-chain (gp130) potently inhibited U266 cells. Remarkably, this effect occurred despite IFN- $\alpha$-augmented secretion of endogenous IL-6. However, examining the IL$6 R$ revealed that IFN- $\alpha$ drastically curtailed expression of the IL-6R $\alpha$ - and $\beta$-chain. This effect occurred on two different levels (protein and mRNA) and by two different mechanisms (directly and indirectly through IL-6). First, IFN- $\alpha$, but not IL-6, greatly decreased gp80 and, to a lesser extent, gp130 mRNA levels which resulted in a loss of IL-6 binding sites. Second, IFN- $\alpha$-induced IL-6 predominantly downregulated membrane-bound gp130. IFN- $\alpha$-mediated decrease of gp80 levels was not detected on IL-6-independent myeloma (RPMI 8226) or myeloid cells (U937). We conclude that IFN- $\alpha$ inhibited IL-6-dependent myeloma cell growth by depriving $\mathrm{U} 266$ cells of an essential component of their autocrine growth loop, a functional IL-6R. (J. Clin. Invest. 1994. 94:2317-2325.) Key words: multiple myeloma - IL-6 dependency - IL-6 receptors - IFN- $\alpha$ treatment • receptor down-regulation
\end{abstract}

\section{Introduction}

Cellular expression of hormone-like growth factor activities and their corresponding cell surface receptors represent fundamental molecular circuits that may spur and sustain uncontrolled growth and metastatic behavior of neoplastic tissues (reviewed in reference 1). The concept of autocrine growth, formulated some time ago (2), has been experimentally verified in numerous in vitro and in vivo models. Ligand-receptor systems for a number of polypeptide hormones, among them several interleukins, have been shown to function in a variety of malignant

Address correspondence to Dr. Michael Schwabe, 1. Medizinische Abteilung Wilhelminenspital der Stadt Wien, Montleartstrasse 37, A-1171 Vienna, Austria. 1994.

Received for publication 22 March 1994 and in revised form 7 July

J. Clin. Invest.

(C) The American Society for Clinical Investigation, Inc. 0021-9738/94/12/2317/09 \$2.00

Volume 94, December 1994, 2317-2325 disorders (1). Among these cytokines, IL-6 has recently attracted considerable attention for its role as in vitro and in vivo growth regulator of several B cell neoplasms $(3,4)$, including multiple myeloma $(\mathrm{MM})^{1}(5,6)$, and solid tumors like malignant melanoma (7).

IL-6 currently is considered to support either an autocrine (5) or paracrine $(6,8)$ growth loop in MM. This view is based upon the original findings that neutralizing anti-IL-6 mABs inhibit, while IL-6, possibly in conjunction with other factors (9-11), stimulates malignant plasma cell growth in vitro (5, $6)$. Several other studies have substantiated and confirmed the in vitro and in vivo role of IL-6 as myeloma growth factor (1216). Although it is not fully understood at what maturation stage plasma cells or their progenitors (17) acquire IL-6 responsiveness, three recent studies suggested that $\mathrm{CD} 38^{+}$bone marrow-derived cells may represent a distinct pool of IL-6-responsive plasma cells $(18-20)$. CD38 ${ }^{+}$myeloma cells were found to express IL- 6 and IL- 6 receptor $(R)$ mRNA and respond to IL-6 with enhanced $\left[{ }^{3} \mathrm{H}\right]$ thymidine incorporation. Although these in vitro data do not confirm a growth-promoting IL-6 activity for $\mathrm{MM}$ in vivo, they provide compelling evidence for a key role of IL- 6 in the pathogenesis of MM. However, CD38 ${ }^{+}$ myeloma cells are not invariably IL- 6 responsive, as evidenced by a subset of $\mathrm{CD} 38^{+}, \mathrm{VLA}^{+}$, and IL-6-resistant myeloma cells (19). Furthermore, expression of the IL-6R $\alpha$-chain mRNA in bone marrow-derived myeloma cells has also been reported $(21,22)$.

Equally important and pertinent to our understanding of autocrine growth loops are agents that can interrupt such loops and, thus, could be of therapeutic value for factor-dependent tumor cell growth. IFN- $\alpha$ is a potent antiproliferative myeloma agent in vitro (23) and has proven clinical efficacy against MM (reviewed in references 24 and 25). In addition, IFN- $\alpha$ is known to affect TNF- $\alpha$-induced growth loops in neoplastic B cells (26). However, very little is known on the effects of IFN- $\alpha$ on the IL-6-IL-6R interactions in myeloma cells.

To investigate the molecular mechanisms by which IFN- $\alpha$ inhibits IL-6-dependent, autocrine myeloma cell growth, we took advantage of the human IgE-secreting myeloma cell line U266 (27). These cells are CD38 ${ }^{+}$(28), express IL-6 mRNA, require IL-6 for growth and survival (27), and are sensitive to growth inhibition by IFN- $\alpha$ (23). U266 cell proliferation can be inhibited by neutralizing anti-IL- 6 mAb or IL- 6 antisense oligonucleotides $(29,30)$. Furthermore, U266 cells express

1. Abbreviations used in this paper: $\mathrm{BS}^{3}$, bis(sulfosuccinimidyl) suberate; MM, multiple myeloma; $\mathrm{R}$, receptor. 
functional cell surface IL-6Rs consisting of the ligand-binding $\alpha$-chain gp80 (31) and the signal-transducing $\beta$-chain gp130 $(32,33)$. The binding of IL-6 to its gp80 receptor subunit (31) triggers the association of the complex with the gp130 component that does not bind IL- 6 by itself (32) but has the ability to transduce an IL-6 signal to postreceptor tyrosine kinases $(34,35)$. Although the chain of events of IL-6-induced signal transduction has not been extensively studied in U266 cells, preliminary evidence indicates that IL-6 triggers the gp130-dependent activation of the protein tyrosine kinase Tyk-2 in these cells (35).

Therefore, we determined the effects of IFN- $\alpha$ on two basic cellular parameters that are required for IL-6-mediated myeloma growth (i.e., IL-6 production and IL-6R $\alpha$ - and $\beta$-chain expression). Here we report that IFN- $\alpha$-mediated growth suppression of myeloma cells in vitro was associated with a seemingly paradoxical increase of the growth factor IL-6. However, these enhanced IL-6 levels were of no biological consequence because IFN- $\alpha$, concomitantly, down-modulated IL-6R expression on a protein and mRNA level and, thus, deprived U266 cells of two essential components of an IL-6 growth loop, the IL-6R gp80 and the IL-6 signal transducer gp130.

\section{Methods}

Cytokines, $m A b$, and other factors. Recombinant, human IL-6 (sp act $4 \times 10^{6} \mathrm{U} / \mathrm{mg}$ protein) was supplied generously by Dr. Steve Clark (Genetics Institute, Cambridge, MA); recombinant, human IFN- $\alpha$ A (sp act $2 \times 10^{8} \mathrm{U} / \mathrm{mg}$ protein) was supplied generously by Dr. Fazlur Khan (Hoffmann-La Roche, Nutley, NJ); and recombinant, human IFN- $\gamma$ (sp act $2.5 \times 10^{7} \mathrm{U} / \mathrm{mg}$ ) was from Biogen (Cambridge, MA). All other cytokines were recombinant, human materials and were obtained through the Biological Response Modifiers Program Repository. The neutralizing IL-6 mAb CLBIL-6/8 is a murine $\operatorname{IgG}_{1 \mathrm{k}}(36)$ and was a kind gift from Dr. Just Brakenhoff (The Netherlands Red Cross, Amsterdam, The Netherlands). Anti-gp80 - (PM1) and anti-gp130-specific (AM64) mAb are described $(32,37)$ and were provided generously by Dr. Tetsuya Taga (Institute for Molecular and Cellular Biology, Osaka University, Osaka, Japan). Isotype control antibodies were purchased from Litton Bionetics (Charleston, SC). PMA was from Sigma Chemical Co. (St. Louis, MO).

Cell culture. The IL-6-dependent, human myeloma cell line U266B 1 and the IL-6-independent myeloma cell line RPMI-8226 were obtained from American Type Culture Collection (Rockville, MD), and myeloid U937 cells were obtained from Dr. Connie R. Faltynek (Sterling Drug, Inc., Malvern, PA). Cells were grown in RPMI-1640 medium supplemented with $10 \%$ heat-inactivated FCS, $2 \mathrm{mM}$ glutamine, and antibiotics in a humidified atmosphere of $5 \% \mathrm{CO}_{2}$ and $95 \%$ air. U266 cells were originally established by Dr. K. Nilsson (University of Uppsala, Uppsala, Sweden) (38), and recently, the biological characteristics of different U266 sublines were described in greater detail $(27,39,40)$. The biological features of the ATCC U266B1 cells used in this study appear to be somewhat different from the U266-1970 and U266-1984 cells described by others $(27,39,40)$. U266 cells were kept at densities ranging from $0.6 \times 10^{6}$ to $2 \times 10^{6}$ cells $/ \mathrm{ml}$, while RPMI-8226 and U937 cells were kept below $1 \times 10^{6}$ cells $/ \mathrm{ml}$ for optimal growth conditions. Different batches of U266 cells at different passage levels (average 1015 passages) gave highly reproducible results.

Proliferation assays. $10^{4} \mathrm{U} 266$ cells were cultured in a total volume of $200 \mu \mathrm{l}$ in 96-well plates either alone or in the presence of cytokines and $\mathrm{mAb}$ for $96 \mathrm{~h}$. During the last $8 \mathrm{~h}$ of the culture period, plates were pulsed with $0.5 \mu \mathrm{Ci}$ of $\left[{ }^{3} \mathrm{H}\right]$ thymidine (sp act $6.7 \mathrm{Ci} / \mathrm{mmol}$; Amersham Corp., Arlington Heights, IL). Plates were harvested using a semiautomatic plate harvester (Skatron, Inc., Sterling, VA) and ethanol-precipitated radioactivity was determined by liquid scintillation counting. Assays were routinely performed in triplicate.
ELISA. Immunoreactive IL-6 was assayed with a commercially available IL-6 ELISA kit (R\&D Systems, Inc., Minneapolis, MN) according to the manufacturer's recommendations. The limit of detection was $\geq 50 \mathrm{pg} / \mathrm{ml}$. Determinations were performed in quadruplicate.

Binding assays. Saturation binding and Scatchard plots were performed as described (33). Briefly, IL-6 was radioiodinated with the diiodinated Bolton Hunter reagent (Dupont-NEN, Boston, MA) to a specific activity of $32 \mu \mathrm{Ci} / \mu \mathrm{g}$ and the bioactivity of labeled IL-6 ( ${ }^{125} \mathrm{I}-$ IL-6) was tested on IL-6-dependent B9 cells. U266 cells were harvested by low speed centrifugation and thoroughly washed (three times) with PBS to ensure removal of cell surface-bound, endogenous IL-6. Note that U266 cells secreted considerable amounts of endogenous IL-6. To ensure that endogenous IL-6 did not skew IL-6R determinations with ${ }^{125}$ I-IL-6, in some experiments cells were "cell surface-stripped" with the acidic glycine solution (41) that is known to effectively remove noncovalently bound molecules from the cell surface. Cell surfacestripped U266 cells expressed comparable IL-6R levels to PBS-washed cells. Saturation binding experiments were performed by incubating 3 $\times 10^{6} \mathrm{U} 266$ cells in $250 \mu \mathrm{l}$ binding buffer (identical to cell culture medium) with increasing concentrations of ${ }^{125}$ I-IL-6 (0.018-7.5 ng) either in the absence or presence of a 500 -fold molar excess of unlabeled IL-6 to determine nonspecific binding. Binding reactions were set up in triplicates and proceeded at $4^{\circ} \mathrm{C}$ for $3 \mathrm{~h}$. Earlier results (33) indicated that ${ }^{125} \mathrm{I}-\mathrm{IL}-6$ equilibrium binding occurs around $3 \mathrm{~h}$. Thereafter, samples were layered onto an oil gradient to separate free from cell-bound radioactivity by spinning in a microcentrifuge. The supernatants were aspirated and the tips of the tubes were cut and counted in a gamma counter.

Affinity-crosslinking and SDS-PAGE. U266 cells were affinitycrosslinked with ${ }^{125}$ I-IL-6 and the noncleavable crosslinker bis(sulfosuccinimidyl) suberate $\left(\mathrm{BS}^{3}\right)$ (Pierce, Rockford, IL) exactly as described (33). Briefly, cells were harvested, washed, and $3 \times 10^{6}$ cells were incubated in $1 \mathrm{ml}$ of binding buffer with $15 \mathrm{ng}{ }^{125} \mathrm{I}-\mathrm{IL}-6$ (7.5 $\times 10^{-10} \mathrm{M}$ ) for $3 \mathrm{~h}$ at $4^{\circ} \mathrm{C}$. During the last $15 \mathrm{~min}, \mathrm{BS}^{3}$ from a $50 \mathrm{mM}$ stock solution in PBS was added to yield a final concentration of $1 \mathrm{mM}$. Samples were layered onto $750 \mu$ l of $10 \%$ sucrose (in PBS) in Eppendorf tubes and spun in a microcentrifuge. Supernatants were aspirated and pellets were lysed with $1 \%$ NP-40 in PBS containing protease inhibitors for $15 \mathrm{~min}$ on ice. Insoluble material was removed by centrifugation, the supernatants were collected, and an equal volume of $2 \times$ reducing electrophoresis sample buffer was added. The samples were stored at $-70^{\circ} \mathrm{C}$ until analysis by $6 \%$ SDS-PAGE under reducing conditions. IL-6R complexes were visualized by autoradiography after exposure for an average of 4-6 d.

Northern blot analyses. gp 80 and gp130 cDNAs were a generous gift from Dr. Tetsuya Taga (Osaka University, Osaka, Japan); a human IFN- $\gamma-\mathrm{R}$ cDNA was a kind gift of Dr. Michel Aguet (University of Zurich, Zurich, Switzerland); and an IL-6 probe was supplied kindly by Dr. Tiziana Musso (National Cancer Institute, Frederick, MD). Treatment of cells with cytokines was performed as indicated in the figure legends. Cells were solubilized with guanidine isothiocyanate, and total RNA was purified by sedimentation through a cesium chloride cushion. For some experiments, total RNA was purified by the RNAzol method (Tel-Test, Inc., Friendswood, TX). $20 \mu \mathrm{g}$ of RNA was electrophoresed on formaldehyde agarose gels and transferred onto Nytran ${ }^{\mathrm{TM}}$ membranes (Schleicher \& Schuell, Inc., Keene, NH). Filters were hybridized for $18 \mathrm{~h}$ at $42^{\circ} \mathrm{C}$ in Hybridisol solution (Oncor Inc., Gaithersburg, MD) with $2 \times 10^{6} \mathrm{cpm} / \mathrm{ml}$ of ${ }^{32} \mathrm{P}$-labeled probes. The probes were a 1.4-kb EspI-FspI gp80, a 2.3-kb PstI gp130, a 0.9-kb PstI IL6, and a 1.4-kb KpnI-PstI IFN- $\gamma$-R cDNA fragment, respectively.

\section{Results}

Among a panel of 12 agents including IL-1 $\beta$, IL-2, IL-3, IL-4, IL-5, IL-6, IL-7, GM-CSF, TNF- $\alpha$, IFN- $\alpha$, IFN- $\gamma$, and PMA, only IL-6, IFN- $\alpha$, IFN- $\gamma$, TNF- $\alpha$, and PMA significantly affected U266 cell proliferation. Fig. $1 A$ shows that IL-6 was the 

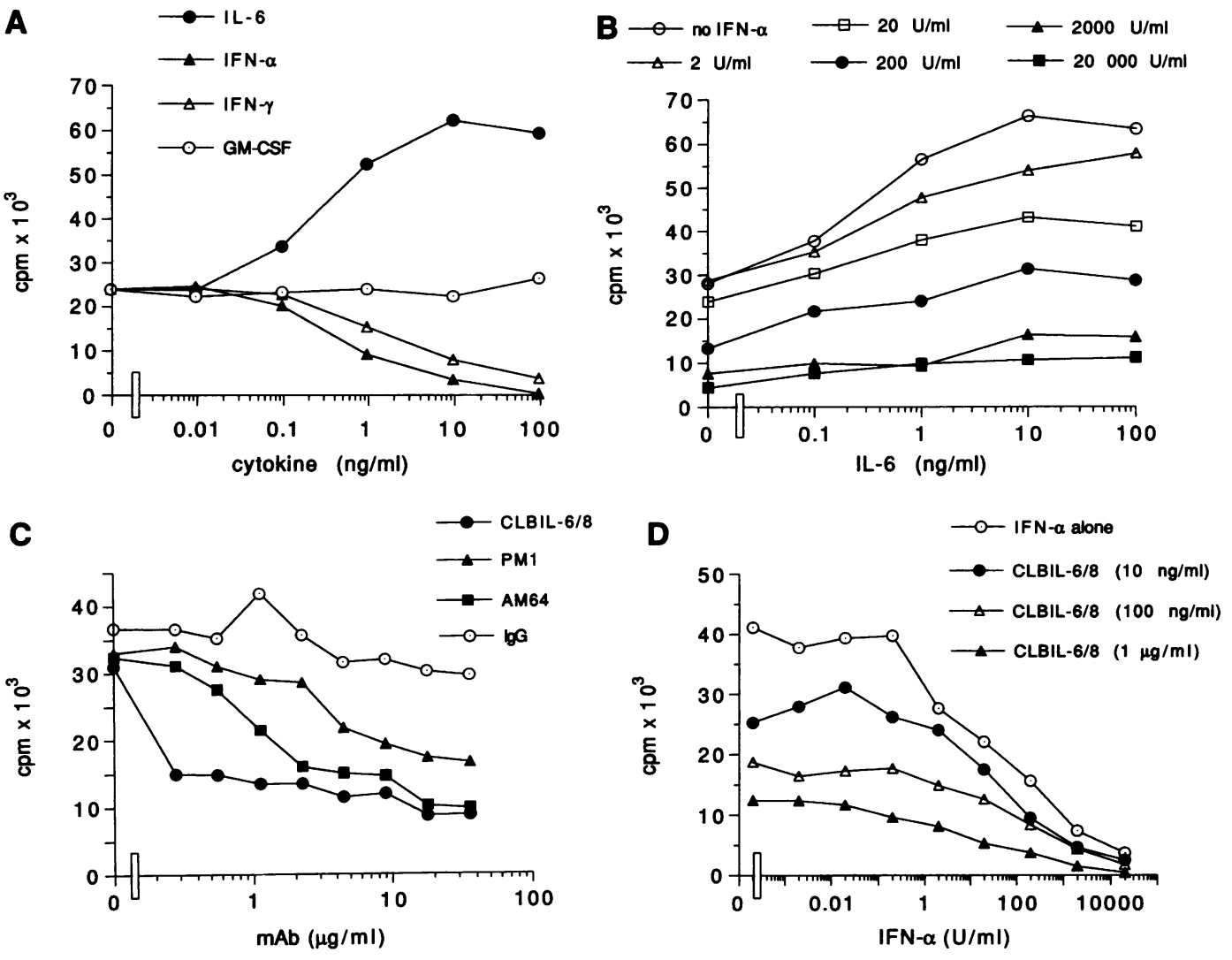

Figure 1. Cytokine- and mAb-mediated growth modulation of U266 cells. $10^{4} \mathrm{U} 266$ cells were cultured in 96-well plates either alone or in the presence of the indicated factors for $96 \mathrm{~h}$. Plates were harvested as described in Methods and incorporated radioactivity was determined by scintillation counting. Results are means of one representative experiment performed in triplicate. $(A)$ U266 cells were cultured either alone or in the presence of increasing concentrations of IL-6 (closed circles), GM-CSF (open circles), IFN- $\alpha$ (closed triangles), or IFN- $\gamma$ (open triangles). Note that $100 \mathrm{ng}$ IFN- $\alpha$ equals $20,000 \mathrm{U}$. (B) U266 cells were cultured either with increasing concentrations of IL-6 alone (open circles), or in the presence of IL- 6 and the indicated amounts of IFN- $\alpha$ : $2 \mathrm{U} / \mathrm{ml}$ (open triangles), $20 \mathrm{U} / \mathrm{ml}$ (open squares), $200 \mathrm{U} / \mathrm{ml}$ (closed circles), 2,000 $\mathrm{U} / \mathrm{ml}$ (closed triangles), or 20,000 U/ml (closed squares). (C) U266 cells were cultured either alone or in the presence of increasing concentrations of CLBIL-6/8 (closed circles), PM1 (closed triangles), AM64 (closed squares), or irrelevant IgG (open circles). (D) U266 cells were cultured either with increasing concentrations of IFN- $\alpha$ alone (open circles), or in the presence of various concentrations of the neutralizing IL-6 mAb CLBIL-6/8: $10 \mathrm{ng} / \mathrm{ml}$ (closed circles), $100 \mathrm{ng} / \mathrm{ml}$ (open triangles), or $1 \mu \mathrm{g} / \mathrm{ml}$ (closed triangles).

only factor that enhanced proliferation greater than or equal to twofold in a concentration-dependent manner, whereas IFN- $\alpha$ inhibited proliferation by $84 \%$ and IFN- $\gamma$ by $72 \%$. TNF- $\alpha$ and PMA inhibited U266 cells by 63 and 75\%, respectively (not shown). For reasons of clarity, Fig. $1 A$ only depicts results obtained for IL-6 (a stimulator), IFN- $\alpha$ and IFN- $\gamma$ (two inhibitors), and GM-CSF (factor with no effect). These results were in good agreement with earlier reports on the antiproliferative effects of IFN- $\alpha$ (23) and IFN- $\gamma$ on U266 cells (39) and support the notion that IL- 6 is a growth factor for this cell line $(27,29$, 42). IL-1, IL-2, IL-3, IL-4, IL-5, IL-7, and GM-CSF, cytokines that were reported previously to affect $B$ cells and myeloma cells to varying degrees $(9-11,42-44)$ had no detectable growth-modulating effects on U266 cells.

Since U266 cells synthesize and secrete minute amounts of IL-6 (29), experiments were carried out to test whether increasing concentrations of the growth factor IL- 6 could counteract the growth inhibitor IFN- $\alpha$. Fig. $1 B$ shows that IL-6 enhanced U266 cell proliferation even in the presence of low IFN- $\alpha$ concentrations $(\leq 200 \mathrm{U} / \mathrm{ml})$. That effect became less pronounced in the presence of higher IFN- $\alpha$ concentrations and was inhibited with concentrations of $\geq 2,000 \mathrm{U} / \mathrm{ml}$ IFN- $\alpha$. Furthermore,
IL- 6 concentrations up to $100 \mathrm{ng} / \mathrm{ml}$ could not overcome high dose IFN-induced growth suppression. These results clearly demonstrated that IFN- $\alpha$-induced negative growth signals dominate growth-promoting IL-6 signals in U266 cells.

The autocrine nature of the IL- 6 growth loop predicts that U266 cells should be prone to growth inhibition by either neutralizing endogenous IL- 6 or by blocking the interaction of IL6 with its receptor (gp80) or its signal transducer (gp130). Fig. $1 C$ shows that this is the case. Three mAbs directed either against IL-6 (CLBIL-6/8), the IL-6R (PM1), or the IL-6 signal transducer (AM64) each inhibited U266 cell growth to varying degrees. CLBIL-6/8 and AM64 were the strongest inhibitors ( $\geq 70 \%$ ), while PM1 was less effective $(50 \%)$. These results are in good agreement with other studies of mAbs directed against components of the IL-6-IL-6R complex $(29,45,46)$.

Neither IFN- $\alpha$ nor any of the mAbs alone could completely suppress U266 growth. Therefore, the effect of the mAbs in combination with IFN- $\alpha$ was tested. As expected, combinations of IFN- $\alpha$ and mAbs exerted additive antiproliferative effects on U266 cells. Fig. $1 D$ shows results obtained with varying concentrations of CLBIL-6/8 and IFN- $\alpha$. Combinations of PM1 and IFN- $\alpha$ or AM64 and IFN- $\alpha$ in the highest doses tested (1 


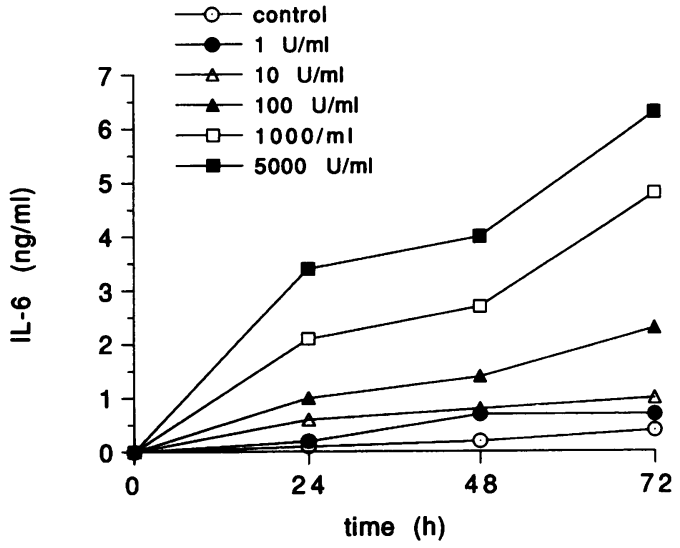

Figure 2. IFN- $\alpha$ increases extracellular IL-6 levels. U266 cells ( 1 $\times 10^{6} \mathrm{cells} / \mathrm{ml}$ ) were cultured in 6-well plates either alone (open circles) or in the presence of IFN- $\alpha$ at $1 \mathrm{U} / \mathrm{ml}$ (closed circles), $10 \mathrm{U} / \mathrm{ml}$ (open triangles), $100 \mathrm{U} / \mathrm{ml}$ (closed triangles), 1,000 U/ml (open squares), or $5,000 \mathrm{U} / \mathrm{ml}$ (closed squares). At the indicated time periods, culture supernatants were removed and tested for immunoreactive IL- 6 by ELISA. Results shown are means of quadruplicate determinations.

$\mu \mathrm{g} / \mathrm{ml} \mathrm{mAb}$ and $20,000 \mathrm{U} / \mathrm{ml}$ IFN- $\alpha$ ) yielded almost superimposable results of $\leq 95 \%$ growth inhibition (not shown).

An obvious question to ask at this point was whether IFN$\alpha$ blocked synthesis and/or secretion of IL-6 in U266 cells. To address that issue, U266 cells were cultured in either the absence or presence of IFN- $\alpha$, and at varying time points supernatants were collected and tested for IL-6 immunoreactivity by ELISA. As shown in Fig. 2, culture supernatants of untreated U266 cells revealed IL- 6 levels in the low picogram range. Surprisingly, IFN- $\alpha$ did not decrease but markedly increased extracellular IL-6 levels in a time- and concentration-dependent fashion. Maximal IL-6 levels $(6.4 \mathrm{ng} / \mathrm{ml})$ were detected after a $72-\mathrm{h}$ culture period with $5,000 \mathrm{U} / \mathrm{ml}$ of IFN- $\alpha$. This effect was not limited to type I IFN. IFN- $\gamma(5,000 \mathrm{U} / \mathrm{ml}, 72 \mathrm{~h})$ induced comparable IL-6 levels (3.4 ng/ml) in U266 cells (data not shown). However, a Northern blot analysis of IFN- $\alpha$-treated cells revealed no effects on IL- 6 mRNA levels over the observed time periods (up to $48 \mathrm{~h}$ ) (see Fig. $5 \mathrm{~B}$ ). Therefore, IFN- $\alpha$ appeared to augment secretion of IL-6. These results are partly in agreement with a recent report by Jourdan et al. (47), who observed that low dose IFN- $\alpha$ enhanced, while high dose IFN$\alpha$ inhibited, proliferation of a different set of human myeloma cells. However, in the case of U266 cells, IFN- $\alpha$-induced extracellular IL-6 apparently had no growth-enhancing effects because no increases in $\left[{ }^{3} \mathrm{H}\right]$ thymidine incorporation were observed at any given IFN- $\alpha$ concentrations tested (range: $0.02-$ $20,000 \mathrm{U} / \mathrm{ml}$ ).

Having established that IFN- $\alpha$-mediated inhibition of U266 cell growth could not be based on suppression of IL- 6 synthesis, experiments were designed to investigate whether IFN- $\alpha$ affected another fundamental component of an autocrine IL-6 growth loop (i.e., the IL-6R). The effect of IFN- $\alpha$ on numbers of IL-6R and equilibrium dissociation constants $\left(K_{d}\right)$ in saturation binding experiments with ${ }^{125} \mathrm{I}-\mathrm{IL}-6$ followed by Scatchard analyses was determined. Fig. $3 A$ shows that ${ }^{125}$ I-IL-6 binding on U266 cells was specific and saturable. Scatchard analyses of the binding data (Fig. $3 \mathrm{~B}$ ) revealed that untreated U266 cells expressed two independent classes of high and low affinity binding sites, yielding 1,185 high affinity $\left(K_{\mathrm{d} 1}=2.9 \times 10^{-11}\right.$ M) and 2,911 low affinity binding sites $\left(K_{\mathrm{d} 2}=1.7 \times 10^{-10}\right.$ $\mathrm{M})$, confirming earlier reports on the binding kinetics of IL-6 on U266 cells $(32,33)$. Treatment with $1,000 \mathrm{U} / \mathrm{ml}$ of IFN- $\alpha$ for $48 \mathrm{~h}$ completely abrogated high affinity IL-6 binding sites and reduced the number of low affinity sites by $\sim 60 \%(1204)$ without changing their affinity $\left(K_{\mathrm{d}}=1.1 \times 10^{-10} \mathrm{M}\right)$.

To determine whether the loss of high affinity binding sites was due to decreased gp130 levels, affinity-crosslinking experiments using ${ }^{125} \mathrm{I}-\mathrm{IL}-6$ were performed to assess the cell surface expression of the IL-6R $\alpha$ - (gp80) and $\beta$-chain (gp130). Previous work from our laboratory showed that affinity-crosslinking with ${ }^{125} \mathrm{I}-\mathrm{IL}-6$ is a versatile method to visualize the ligandbinding gp80 and the signal-transducing gp130 IL-6R subunits (33). Crosslinking of ${ }^{125}$ I-IL-6 to untreated U266 cells (Fig. $4 A$, lane 1) gave rise to four radioactively labeled receptor complexes comprising one or two ${ }^{125} \mathrm{I}-\mathrm{IL}-6$ molecules crosslinked to one gp80 or one gp130 molecule, respectively (33). The 100- and $120-\mathrm{kD}$ complexes correspond to gp80 and the $145-$ and $165-\mathrm{kD}$ complexes to gp130. IL-6 pretreatment (30 $\mathrm{ng} / \mathrm{ml}$ ) for 24 or $48 \mathrm{~h}$ led to a disappearance of the labeled receptor complexes. This is based presumably on the reported capacity of IL-6 to internalize (48) and thereby to down-regulate its own gp80 and gp130 receptor components (33). IFN- $\alpha$ treatment $(2,000 \mathrm{U} / \mathrm{ml})$ also markedly decreased ${ }^{125} \mathrm{I}-$ IL-6-mediated receptor complex formation, although to a lesser extent than IL-6, while PMA $(50 \mathrm{ng} / \mathrm{ml})$ induced an effect comparable with IL-6.

To test whether IFN- $\alpha$-mediated IL-6R down-regulation would also occur on IL-6-independent myeloma cells, similar experiments were performed with RPMI-8226 cells. These cells are sensitive to growth inhibition by IFN- $\alpha$ (49), but do not respond to IL-6 with enhanced growth $(6,33)$. As shown in Fig. $4 B$, untreated RPMI-8226 cells primarily gave rise to the $145-$ and $165-\mathrm{kD}$ bands, due to relatively higher gp130 cell surface levels of these cells (33). IFN- $\alpha$ treatment $(2,000 \mathrm{U} /$ $\mathrm{ml}, 24 \mathrm{~h}$ ) clearly up-regulated gp80 and, to a lesser extent, also gp130 complexes. These latter data indicated that IFN- $\alpha$ does not invariably down-regulate the IL-6R on all myeloma cells.

Although these results strongly suggested that IFN- $\alpha$ decreased gp80 and gp130 cell surface levels on U266 cells (heterologous IL-6R down-regulation), it was not immediately apparent whether this effect was direct or indirect. Since IFN- $\alpha$ increased IL- 6 release in U266 cells, the possibility had to be considered that the observed down-regulation of the IL-6R was in fact due to IL-6 (homologous IL-6R down-regulation). From the data shown in Fig. 2, one would expect $\sim 3 \mathrm{ng} / \mathrm{ml}$ of IL6 to be induced by $2,000 \mathrm{U} / \mathrm{ml}$ of IFN- $\alpha$ during a 48 -h culture period. This amount of IL- 6 could suffice to induce appreciable, homologous receptor down-regulation. Therefore, U266 cells were treated with IFN- $\alpha(2,000 \mathrm{U} / \mathrm{ml})$ for $48 \mathrm{~h}$ either in the absence or presence of a neutralizing anti-IL-6 mAb (CLBIL6/8) $(15 \mu \mathrm{g} / \mathrm{ml})$. Fig. $4 C$ shows that CLBIL-6/8 (lane 2), but not an irrelevant isotype control (lane 4), was able to prevent the IFN- $\alpha$-mediated decrease of the $145-$ and $165-\mathrm{kD}$ bands (gp130) but not of the 100- and 120-kD bands (gp80). CLBIL-6/8 and irrelevant IgG 1 had no effect on IL-6R complex formation (Fig. $4 C$, lanes 1 and 3 ). These results suggested that IFN- $\alpha$ directly (not through IL-6) down-regulated gp80, while the loss of gp130 cell surface levels appeared to be indirectly mediated through IL-6. Consequently, considerable num- 


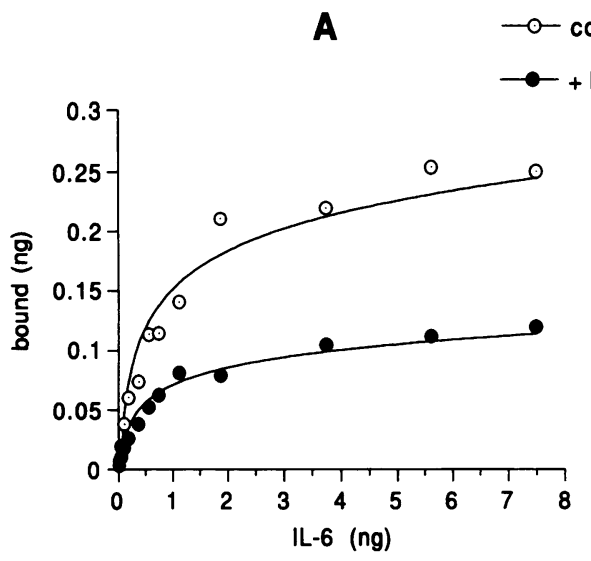

B

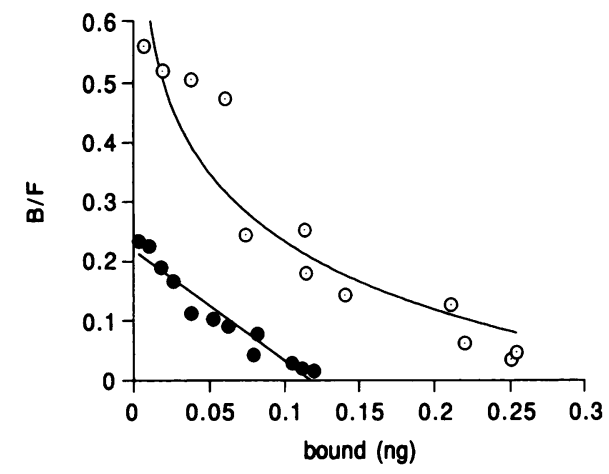

Figure 3. Saturation ${ }^{125} \mathrm{I}-\mathrm{IL}-6$ binding and Scatchard analysis. (A) $3 \times$ $10^{6}$ untreated (open circles) or IFN$\alpha$-treated (1,000 U/ml, $48 \mathrm{~h}$ ) (closed circles) U266 cells were reacted in $250 \mu \mathrm{l}$ binding buffer with increasing concentrations of ${ }^{125} \mathrm{I}-\mathrm{IL}-6$ (ranging from 0.018 to $7.5 \mathrm{ng}$ ) for $3 \mathrm{~h}$ at $4^{\circ} \mathrm{C}$. Thereafter, cells were spun over an oil gradient and cell-bound radioactivity was determined in a gamma counter. Results are means of specific binding obtained in one representative experiment performed in triplicate. (B) Scatchard transformation of the specific binding data. bers of cell surface IL-6Rs were lost during IFN treatment due to homologous (IL-6-mediated) and heterologous (IFN- $\alpha-$ mediated) receptor down-regulation.

The distinct IFN- $\alpha$ and IL-6 effects on gp80 and gp130 protein levels suggested that both cytokines could also differentially regulate gp80 and gp130 mRNA levels. To test this notion, U266 cells were cultured for different lengths of time in the presence of IL-6 $(30 \mathrm{ng} / \mathrm{ml})$ or IFN- $\alpha(2,000 \mathrm{U} / \mathrm{ml})$ followed by Northern blot analyses. As shown in Fig. 5, untreated cells expressed basal levels of 5.5-kb gp80 and 7.0-kb gp130 mRNAs. IL-6 treatment did not significantly modify this expression (Fig. $5 \mathrm{~A}$ ). On the contrary, IFN- $\alpha$ treatment (Fig. $5 \mathrm{~B}$ ) clearly down-modulated gp80 mRNA expression in a time-dependent manner. After a steep initial increase above basal levels by $1 \mathrm{~h}$ of stimulation, gp80 mRNA levels rapidly decreased and virtually no gp80 mRNA was detected at $36 \mathrm{~h}$. IFN- $\alpha$ also
A

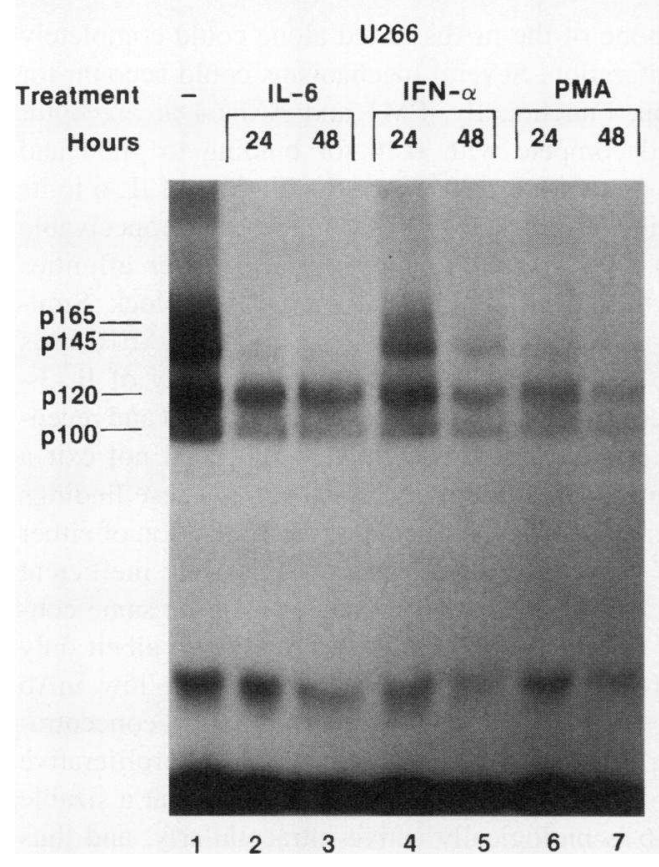

B

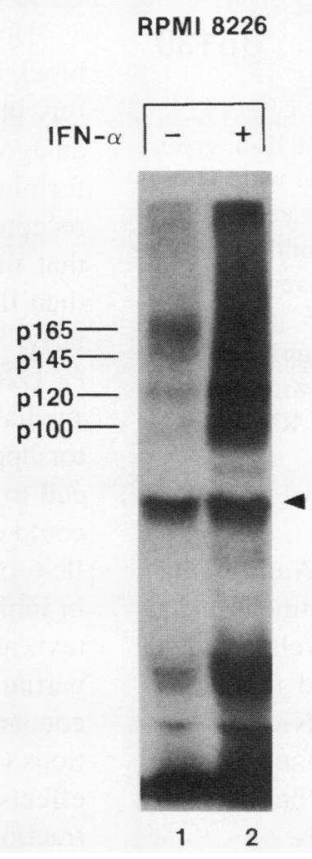

C

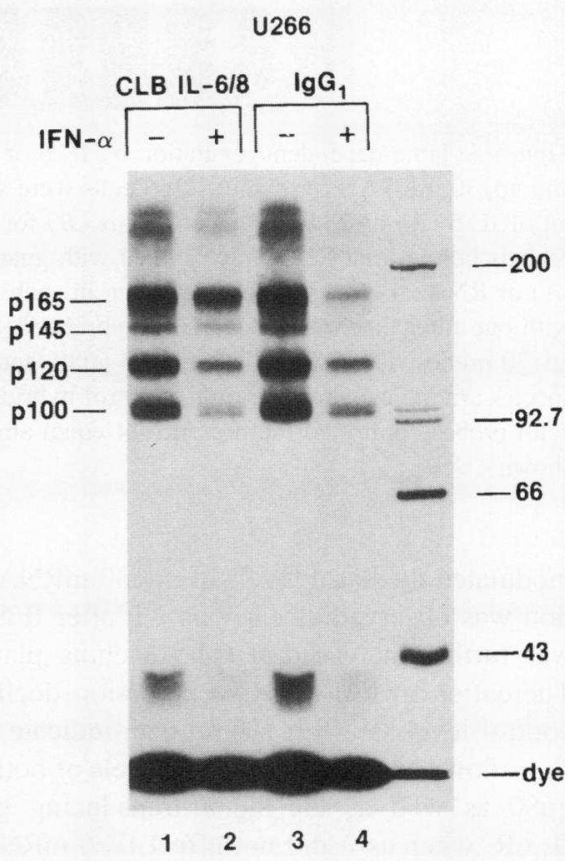

Figure 4. Affinity-crosslinking of the IL-6R. (A) U266 cells were left untreated (lane 1), treated with IL-6 ( $30 \mathrm{ng} / \mathrm{ml}$ ) (lanes 2 and 3 ), IFN- $\alpha$ $(2,000 \mathrm{U} / \mathrm{ml}$ ) (lanes 4 and 5), or PMA ( $50 \mathrm{ng} / \mathrm{ml}$ ) (lanes 6 and 7) for 24 or $48 \mathrm{~h}$, respectively. Cells were harvested, washed, and subjected to affinity-crosslinking with ${ }^{125}$ I-IL-6 and BS ${ }^{3}$. Clarified NP-40 lysates of the samples were separated by $6 \%$ SDS-PAGE followed by autoradiography. IL-6R complexes in kilodaltons are indicated on the left. $(B)$ RPMI-8226 cells were left untreated (lane 1$)$ or treated with IFN- $\alpha(2,000 \mathrm{U} / \mathrm{ml})$ for $24 \mathrm{~h}$ (lane 2). Cells were affinity-crosslinked with ${ }^{125} \mathrm{I}-\mathrm{IL}-6$ and analyzed by $6 \%$ SDS-PAGE followed by autoradiography. The 70-kD band (arrowhead) obtained with RPMI-8226 cells is a nonspecific crosslinking artifact and does not represent an IL-6R complex (33). ( $C$ ) U266 cells were cultured with CLBIL-6/8 (15 $\mu \mathrm{g} / \mathrm{ml}$ ) (lanes 1 and 2 ) or an irrelevant isotype control antibody ( $15 \mu \mathrm{g} / \mathrm{ml}$ ) (lanes 3 and 4 ) either alone (lanes 1 and 3 ) or in the presence of IFN- $\alpha(2,000 \mathrm{U} / \mathrm{ml}$ ) (lanes 2 and 4). After $48 \mathrm{~h}$, cells were harvested and analyzed by affinity-crosslinking, SDSPAGE, and autoradiography as in $A$ and $B$. Molecular mass markers in kilodaltons are indicated on the right. 
A

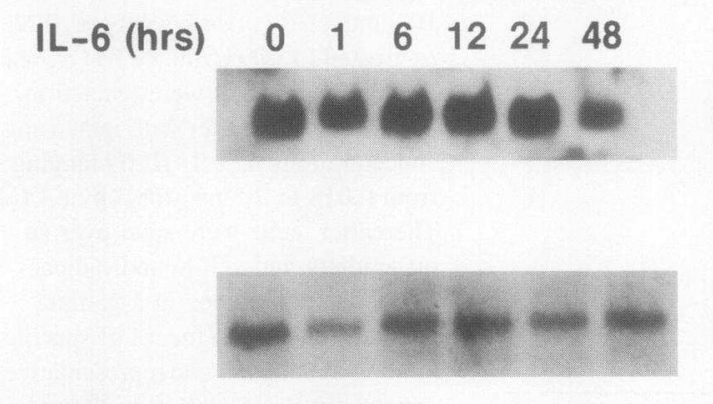

gp80

gp130

B
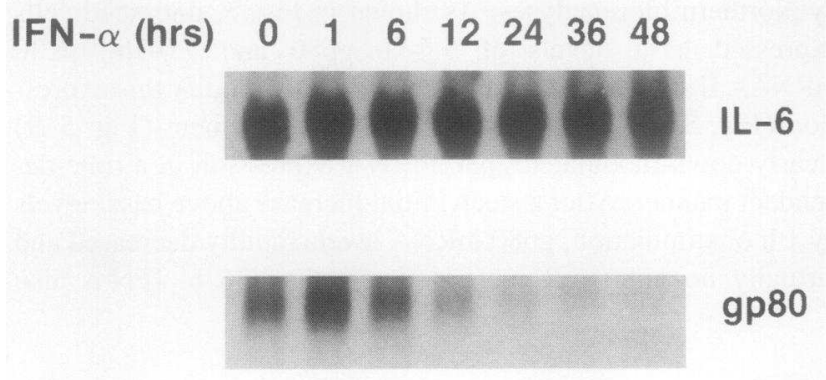

gp80

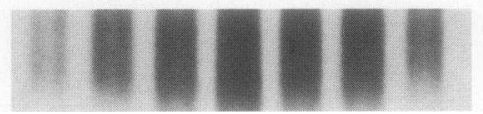

gp130

Figure 5. Time-dependent regulation by IL-6 or IFN- $\alpha$ of IL-6, gp80, and gp130 mRNA expression. U266 cells were stimulated with $30 \mathrm{ng} /$ $\mathrm{ml}$ of IL-6 $(A)$ or $2,000 \mathrm{U} / \mathrm{ml}$ of IFN- $\alpha(B)$ for the indicated time periods before total RNA was isolated with guanidine isothiocyanate $(A)$ or RNAzol $(B)$. The results shown in each panel were obtained with one filter that was sequentially hybridized with IL-6, gp80, or gp130 probes. The 1.3-kb IL-6, 5.5-kb gp80, and 7.0-kb gp130 mRNA species are indicated on the right. Control hybridizations with rRNA or actin probes confirmed the presence of equal amounts of RNA (not shown).

modulated the basal levels of gp130 mRNA. mRNA up-regulation was observed as early as $1 \mathrm{~h}$ after IFN- $\alpha$ treatment and it was further increased at $6 \mathrm{~h}$, reaching plateau levels at $12 \mathrm{~h}$. Thereafter, gp130 mRNA expression declined and fell below control levels at $48 \mathrm{~h}$. These data indicate that IFN- $\alpha$, but not IL-6, down-modulated mRNA levels of both the ligand-binding gp80 as well as the signal-transducing gp130 chain of the IL-6R, whereas it did not affect IL-6 mRNA levels.

To test whether the observed IFN- $\alpha$ effects on gp 80 mRNA levels were specific, U266 (Fig. 6, $A$ and $B$ ) and U937 cells (Fig. $6 C)$ were treated with IFN- $\gamma(2,000 \mathrm{U} / \mathrm{ml})$, TNF- $\alpha(10$ $\mathrm{ng} / \mathrm{ml}$ ), or PMA ( $50 \mathrm{ng} / \mathrm{ml})$. As shown in Fig. $6 A$, IFN- $\gamma$ and TNF- $\alpha$, two agents that inhibit U266 cells, did not significantly change gp80 mRNA levels, whereas PMA caused a reduction comparable with IFN- $\alpha$. Therefore, factor-induced growth inhibition of U266 cells was not invariably associated with downmodulation of the IL-6R $\alpha$-chain mRNA. To determine whether the IFN- $\alpha$ effect on gp80 mRNA levels was gp80 specific, the same filter shown in Fig. $6 A$ was hybridized with a probe for the human IFN- $\gamma$-R. As shown in Fig. $6 B$, TNF- $\alpha$ and PMA but not IFN- $\alpha$ or IFN- $\gamma$ down-modulated steady-state mRNA levels of the human IFN- $\gamma-\mathrm{R}$. Finally, to compare cytokineinduced IL-6R modulation in IFN- $\alpha$-sensitive myeloid cells, U937 cells were stimulated with the same agents and analyzed by Northern blotting for gp80 expression. As shown in Fig. 6 $C$, IFN- $\alpha$, IFN- $\gamma$, and TNF- $\alpha$ slightly increased expression of gp80 mRNA levels in U937 cells. These latter results substantiated the notion that IFN- $\alpha$-mediated disruption of an IL-6dependent autocrine growth loop in U266 myeloma cells was specifically and predominantly due to a potent down-modulation of the IL-6R $\alpha$-chain gp80.

\section{Discussion}

IL-6 fulfills the requirements for an autocrine growth system on U266 cells. We have confirmed that U266 cells express IL6 mRNA and protein $(29,30)$ and the $\alpha$ - and $\beta$-chain of the IL-6R (32, and this study). Of 11 cytokines tested, only IL-6 significantly enhanced $\left[{ }^{3} \mathrm{H}\right]$ thymidine incorporation. Moreover, antibody inhibition experiments demonstrated that cellular proliferation could be blocked by interfering with IL-6 (CLBIL$6 / 8$ ), the IL-6R gp80 (PM1), or the IL-6 signal transducer gp130 (AM64), as previously shown for U266 (29) and other IL-6-responsive cells $(45,46)$. Although Levy et al. (30) failed to inhibit $\mathrm{U} 266$ cells by anti-IL- $6 \mathrm{mAb}$, they, and another group (29) inhibited U266 growth by IL-6 antisense oligonucleotides, thus further confirming the strict requirement of IL- 6 by U266 cells.

However, none of the mAbs tested alone could completely block cell proliferation. Several mechanisms could account for this observation. Functionally, PM1 and AM 64 are receptor antagonists and compete with IL-6 for binding to gp80 and forming a complex with gp 130 . Since the binding of IL- 6 to its receptor is of high affinity (10-100 pM range), it is conceivable that the mAbs bind to gp80 and gp130 with lower affinities than IL-6 and, thus, can only induce a partial IL-6 block. Similarly, Sidell et al. (45) reported that PM1 inhibited AF10 cells (a U266 clone) by only 40\%. Furthermore, a study of IL-3mediated autocrine growth loops revealed that ligand and receptor apparently can interact intracellularly and need not exit a cell to induce a growth stimulatory signal (50). These findings could easily explain why mAb-mediated neutralization of either IL-6 or any of its receptor components is relatively inefficient in inhibiting IL-6-dependent myeloma cells. In the same context, as shown in Fig. $1 C$, CLBIL-6/8 effectively, albeit only partially ( $\geq 50 \%$ ), inhibited U266 cell growth at low mAb concentrations $(\leq 1 \mu \mathrm{g} / \mathrm{ml})$, but increasing $\mathrm{mAb}$ concentrations ( $\geq 10 \mu \mathrm{g} / \mathrm{ml}$ ) had only minor additional antiproliferative effects. These results could reflect the possibility that a sizable fraction of IL-6 is biologically active intracellularly, and thus evades neutralization by mAb. It is noteworthy to mention that two groups $(29,30)$ found IL- 6 antisense oligonucleotide-mediated inhibition to be more effective than mAb-mediated inhibition of U266 cell growth.

IFN- $\alpha$-mediated inhibition was clearly more effective than mAb-mediated inhibition. IFN- $\alpha$ alone inhibited U266 cells by $84 \%$ and that value increased to $96 \%$ when combined with 1 $\mu \mathrm{g} / \mathrm{ml}$ of CLBIL- $6 / 8$ or any of the IL-6R mAbs. Importantly, IFN- $\alpha$ exerted a dominant negative growth signal, because ex- 
A

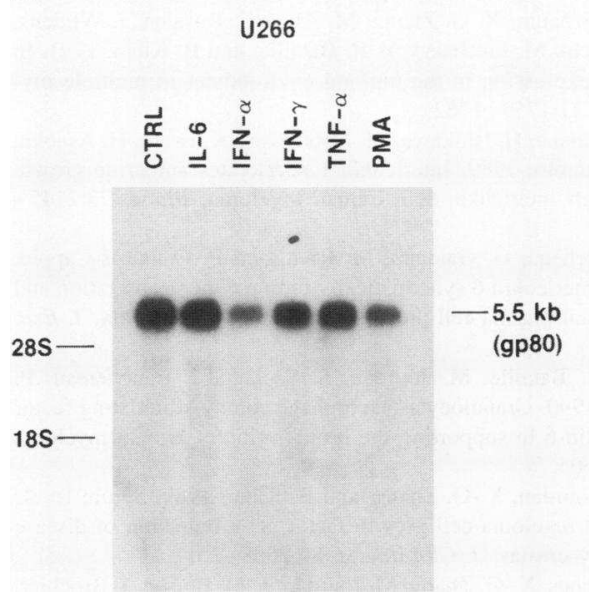

B

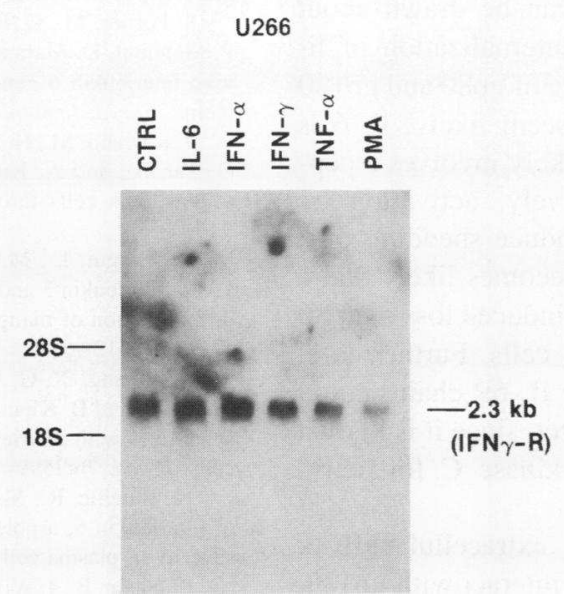

C

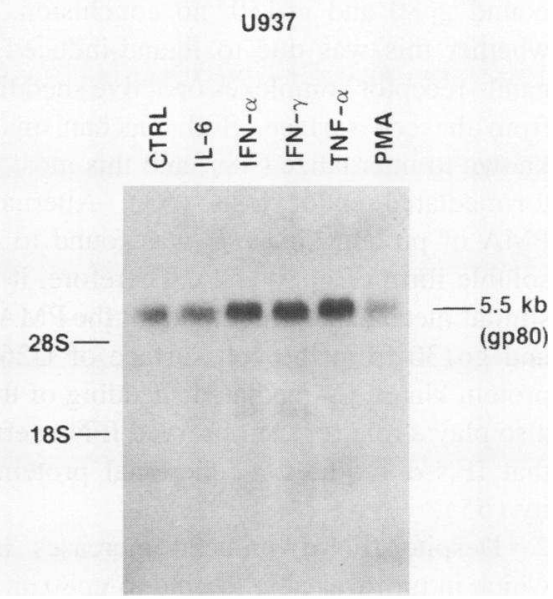

Figure 6. IFN- $\alpha$-specific down-modulation of gp80 mRNA. U266 cells ( $A$ and $B$ ) or U937 cells $(C)$ were incubated for $24 \mathrm{~h}$ with IL-6 ( $10 \mathrm{ng}$ / $\mathrm{ml})$, IFN- $\alpha(2,000 \mathrm{U} / \mathrm{ml})$, IFN- $\gamma(2,000 \mathrm{U} / \mathrm{ml})$, TNF- $\alpha(10 \mathrm{ng} / \mathrm{ml})$, or PMA $(50 \mathrm{ng} / \mathrm{ml})$. Northern blots were performed with guanidine isothiocyanate-extracted RNA. In $A$ and $C$ filters were hybridized with a gp 80 probe and in $B$ the same filter shown in $A$ was stripped and rehybridized with an IFN- $\gamma-\mathrm{R}$ probe. The $5.5-\mathrm{kb}$ gp 80 and $2.3-\mathrm{kb}$ IFN- $\gamma-\mathrm{R}$ mRNAs are indicated on the right. Control hybridizations with rRNA probes confirmed the presence of equal amounts of RNA (not shown).

ogenously added IL-6 (up to $100 \mathrm{ng} / \mathrm{ml}$ ) could not counteract growth suppression. In this respect IFN- $\alpha$-mediated inhibition of myeloma cells differs from retinoic acid-mediated inhibition that is not dominant and can be reversed by IL-6 (45). These results strongly suggested that IFN- $\alpha$ interfered with a critical cellular component that is required by IL- 6 to drive U266 cell proliferation. However, that component was not IL- 6 itself since IFN- $\alpha$ augmented secretion of IL- 6 and had no effect on IL-6 mRNA levels.

The critical, IFN- $\alpha$-regulated component of IL- 6 -mediated growth stimulation of U266 cells appeared to be the IL-6R. Scatchard analyses indicated that IFN- $\alpha$ led to a complete loss of high affinity binding sites and reduced the number of low affinity binding sites by $\sim 60 \%$. Affinity-crosslinking experiments verified that the loss of high affinity binding sites was due to a loss of the cell surface expression of the IL-6 signal transducer gp130 and that the reduction of low affinity binding sites correlated with a reduced appearance of gp 80 crosslinked to ${ }^{125}$ I-IL-6. However, while the loss of membrane-bound gp80 appeared to be a direct IFN- $\alpha$ effect, the loss of gp130 was mediated primarily by endogenous IL-6, as revealed by mAb neutralization experiments with CLBIL-6/8. These results were substantiated by the Northern blots. IL-6 had no effect on gp 80 or gp130 mRNA levels which indicated that IL-6 primarily regulated the cell surface levels of its receptor components. These results differ somewhat from IL-6-mediated regulation of gp80 and gp130 mRNA levels in monocytes and hepatocytes $(51,52)$. Conversely, IFN- $\alpha$ primarily regulated the IL-6R components on an mRNA level. After a transient increase, both mRNA species rapidly declined after continuous exposure to IFN- $\alpha$. The time course of the IFN- $\alpha$-mediated regulation of the IL-6R components indicate that by $48 \mathrm{~h}$ very little receptor protein should be available at the cell surface, because of IL-6-mediated loss of membrane-bound gp130 and the lack of newly synthesized gp80 due to greatly reduced gp80 mRNA levels. This timely staged sequence of events could explain why IFN- $\alpha$-mediated growth inhibition is not an immediate effect and takes at least $48-72 \mathrm{~h}$ to become experimentally detectable.
Interestingly, IFN- $\gamma$ had little to no effect on gp80 mRNA levels (Fig. $6 \mathrm{~A}$ ). These data are in very good agreement with results obtained by Jernberg-Wiklund et al. (39) who concluded that type I and type II IFNs inhibit U266 cells by different mechanisms. Our data, however, differ from a study by Portier et al. (22) who showed that IFN- $\gamma$ reduced gp80 mRNA levels in XG1 and XG-5 human myeloma cells, which do not secrete IL-6 but are sensitive to growth inhibition by IFN- $\gamma$. These results further emphasize the biological heterogeneity of MM cell lines.

Consequently, one can conclude that IFN- $\alpha$ inhibited U266 cell growth by targeting the IL-6R $\alpha$-chain specifically. This effect appeared to be specific for IL-6-dependent myeloma cells because IFN- $\alpha$-induced growth inhibition was associated with up-regulation of gp80 levels on IL-6-independent myeloma (RPMI-8226) (Fig. 4 B) and myeloid U937 cells (Fig. $6 C$ ); similar observations were made by Lasfar et al. (49). Importantly, these investigators also reported IFN- $\alpha$-mediated gp80 down-regulation on another IL-6-dependent myeloma cell line (XG-1) and, similarly, IFN- $\alpha$-mediated gp80 up-regulation on another IL-6-independent myeloma cells (RPMI8226 ). Hence, it appears that IFN- $\alpha$ has the capacity to specifically down-regulate the IL-6R in IL-6-dependent but not in IL-6-independent myeloma or other cell types. Interestingly, Sidell et al. (45) recently reported another agent, retinoic acid, that appeared to specifically down-regulate gp80 levels in IL-6-dependent AF10 myeloma cells.

Furthermore, it cannot be determined from our data whether IFN- $\alpha$ decreased the half-life of the gp 80 mRNA, a mechanism that has been shown for other IFN-regulated mRNAs (26), or whether IFN- $\alpha$ induced a transcriptional block. Nevertheless, the IFN- $\alpha$ effect appeared to be highly specific. IFN- $\gamma$ and TNF- $\alpha$, which inhibited U266 cells to comparable degrees like IFN- $\alpha$, had no effect on gp80 mRNA levels. In addition, it is unlikely that the IFN- $\alpha$ effect was due to general inhibition of protein synthesis or reduced transcriptional activity, since IFN- $\alpha$ did not affect gp130 protein levels and led to a significant increase of gpl30 mRNA at a time point $(12 \mathrm{~h})$ when there was only very little gp80 mRNA left. 
Although our results clearly indicated a loss of membranebound gp80 and gp130, no conclusions can be drawn about whether this was due to ligand-induced internalization of ligand-receptor complexes or active shedding of gp80 and gp130 from the cell surface. Both mechanisms seem likely. IL-6 is known to internalize (48), and this most likely involves receptor-mediated endocytosis (53). Alternatively, activation by PMA of protein kinase $\mathrm{C}$ was found to induce shedding of a soluble form of gp80 (54). Therefore, it becomes likely that a similar mechanism accounted for the PMA-induced loss of gp80 and gp130 from the cell surface of U266 cells. Furthermore, protein kinase $\mathrm{C}$-mediated shedding of the IL-6R chains could also play a role for the observed IFN- $\alpha$ effect, since it is known that IFN- $\alpha$ requires a functional protein kinase $\mathrm{C}$ for activity (55).

Despite IFN- $\alpha$-induced increases in extracellular IL-6, which in turn was able to bind to gp80 and interact with gp130, we did not detect enhanced cellular proliferation. This differs from the report by Jourdan et al. (47) who observed enhanced myeloma cell growth with low IFN- $\alpha$ concentrations. The inability of IL- 6 to exert a biological effect in the presence of IFN- $\alpha$ could suggest a block in IL- 6 signal transduction. In that respect, it is noteworthy to mention that IFN- $\alpha$ and IL-6 were shown recently to activate the same members of the Jak/Tyk family of protein tyrosine kinases, Jak-1 $(34,35,56)$ and Tyk-2 $(35,57)$. IFN- $\alpha$ may use IFN- $\alpha-$ specific as well as shared signaling molecules. Therefore, IFN- $\alpha$ may divert the shared signals from the IL-6R system, thereby inducing an effective biological IL- 6 block. These considerations may explain how two factors that share common signal transduction pathways can still induce entirely distinct biological effects.

Finally, if the results of this in vitro study had any bearings for IFN- $\alpha$ therapy of MM, then it would seem that high IFN- $\alpha$ doses were more likely to achieve favorable response rates in IL-6-dependent myelomas. In this regard, it is interesting to note that the optimal dose, schedule, and administration of IFN- $\alpha$ in MM remain to be established (24).

\section{Acknowledgments}

We thank Drs. Steve Clark, Fazlur Khan, Michel Aguet, Tiziana Musso, Just Brakenhoff, and Tetsuya Taga for kindly supplying and providing reagents; Dr. Simon Panzer (University of Vienna) for sharing his computer; and Dr. Scott Durum and Dr. Joost Oppenheim for critically reading the manuscript.

\section{References}

1. Lang, R. A., and A. W. Burgess. 1990. Autocrine growth factors and tumourigenic transformation. Immunol. Today. 11:244-249.

2. Sporn, M. B., and A. B. Roberts. 1985. Autocrine growth factors and cancer. Nature (Lond.). 313:745-747.

3. Biondi, A., V. Rossi, R. Bassan, T. Barbui, S. Bettoni, M. Sironi, A. Mantovani, and A. Rimbaldi. 1989. Constitutive expression of the interleukin-6 gene in chronic lymphocytic leukemia. Blood. 73:1279-1284.

4. Freeman, G. J., A. S. Freedman, S. N. Rabinowe, J. M. Segil, J. Horowitz, K. Rosen, J. F. Whitman, and L. M. Nadler. 1989. Interleukin 6 gene expression in normal and neoplastic B cells. J. Clin. Invest. 83:1512-1517.

5. Kawano, M., T. Hirano, T. Matsuda, T. Taga, Y. Horii, K. Iwato, H. Asaoku, B. Tang, O. Tanabe, H. Tanaka, et al. 1988. Autocrine generation and requirement of BSF-2/IL-6 for human multiple myelomas. Nature (Lond.). 332:83-85.

6. Klein, B., X.-G. Zhang, M. Jourdan, J. Content, F. Houssiau, L. Aarden, M. Piechaczyk, and R. Bataille. 1988. Paracrine rather than autocrine regulation of myeloma-cell growth and differentiation by interleukin-6. Blood. 73:517-526.

7. Lu, C., and R. S. Kerbel. 1993. Interleukin 6 undergoes transition from paracrine growth inhibitor to autocrine stimulator during human melanoma progression. J. Cell Biol. 120:1281-1288.

8. Portier, M., G. Rajzbaum, X. G. Zhang, M. Attal, C. Rusalen, J. Wijdens, P. Mannoni, D. Maraninchi, M. Piechaczyck, R. Bataille, and B. Klein. 1991. In vivo interleukin 6 gene expression in the tumoral environment in multiple myleoma. Eur. J. Immunol. 21:1759-1762.

9. Kawano, M., H. Tanaka, H. Ishikawa, M. Nobuyoshi, K. Iwato, H. Asaoku, O. Tanabe, and A. Kuramoto. 1989. Interleukin-1 accelerates autocrine growth of myeloma cells through interleukin-6 in human myeloma. Blood. 73:21452150 .

10. Bergui, L., M. Schena, G. Gaidano, M. Riva, and F. Caligaris-Cappio. 1989. Interleukin 3 and interleukin 6 synergistically promote the proliferation and differentiation of malignant plasma cell precursors in multiple myeloma. $J$. Exp. Med. 170:613-618.

11. Zhang, X.-G., R. Bataille, M. Jourdan, S. Saeland, J. Banchereau, P. Mannoni, and B. Klein. 1990. Granulocyte-macrophage colony-stimulating factor synergizes with interleukin- 6 in supporting the proliferation of human myeloma cells. Blood. 76:2599-2605.

12. Bataille, R., M. Jourdan, X.-G. Zhang, and B. Klein. 1989. Serum levels of interleukin 6, a potent myeloma cell growth factor, as a reflection of disease severity in plasma cell dyscrasias. J. Clin. Invest. 84:2008-2011.

13. Klein, B., J. Wijdenes, X.-G. Zhang, M. Jourdan, J.-M. Boiron, J. Brochier, J. Liautard, M. Merlin, C. Clement, B. Morel-Fournier, et al. 1991. Murine antiinterleukin-6 monoclonal antibody therapy for a patient with plasma cell leukemia. Blood. 78:1198-1204.

14. Ludwig, H., D. Nachbaur, E. Fritz, M. Kraisner, and H. Huber. 1991. Interleukin-6 is a prognosis factor in multiple myeloma. Blood. 77:2794-2799.

15. Okuno, Y., T. Takahashi, A. Suzuki, M. Fukumoto, K. Nakamura, H. Fukui, Y. Koishihara, Y. Ohsugi, and H. Imura. 1992. Acquisition of growth autonomy and tumorigenicity by an interleukin 6-dependent human myeloma cell line transfected with interleukin 6 cDNA. Exp. Hematol. 20:395-400.

16. Suzuki, H., K. Yasukawa, T. Saito, R. Goitsuka, A. Hasegawa, Y. Ohsugi, T. Taga, and T. Kishimoto. 1992. Anti-human interleukin-6 receptor antibody inhibits human myeloma growth in vivo. Eur. J. Immunol. 22:1989-1993.

17. Barlogie, B., J. Epstein, P. Selvanayagam, and R. Alexanian. 1989. Plasma cell myeloma-new biological insights and advances in therapy. Blood. 73:865872.

18. Hata, H., H. Xiao, M. T. Petrucci, J. Woodliff, R. Chang, and J. Epstein. 1993. Interleukin-6 gene expression in multiple myeloma: a characteristic of immature tumor cells. Blood. 81:3357-3364.

19. Kawano, M. M., N. Huang, H. Harada, Y. Harada, A. Sakai, H. Tanaka, K. Iwato, and A. Kuramoto. 1993. Identification of immature and mature myeloma cells in the bone marrow of human myelomas. Blood. 82:564-570.

20. Nishimoto, N., A. Ogata, Y. Shima, Y. Tani, H. Ogawa, M. Nakagawa, H. Sugiyama, K. Yoshizaki, and T. Kishimoto. 1994. Oncostatin M, leukemia inhibitory factor, and interleukin- 6 induce the proliferation of human plasmacytoma cells via the common signal transducer, gp130. J. Exp. Med. 179:13431347.

21. Fiedler, W., H. J. Weh, E. Suciu, C. Wittlief, C. Stocking, and D. K. Hossfeld. 1990. The IL-6 gene but not the IL-6 receptor gene is occasionally rearranged in patients with multiple myeloma. Leukemia. 4:462-465.

22. Portier, M., X.-G. Zhang, E. Caron, Z.-Y. Lu, R. Bataille, and B. Klein 1993. $\gamma$-Interferon in multiple myeloma: inhibition of interleukin-6 (IL-6)-dependent myeloma cell growth and downregulation of IL-6-receptor expression in vitro. Blood. 81:3076-3082.

23. Brenning, G., H. Jernberg, M. Gidlund, O. Sjoeberg, and K. Nilsson. 1986 The effect of $\alpha$ and $\gamma$-interferon on proliferation and production of IgE and $\beta_{2-}$ microglobulin in the human myeloma cell line U-266 and in an $\alpha$-interferon resistant U-266 subline. Scand. J. Haematol. 37:280-288.

24. Avvisati, G., and F. Mandelli. 1992. The role of interferon- $\alpha$ in the management of myelomatosis. Hematol. Oncol. Clin. N. Am. 6:395-405.

25. Alexanian, R., and M. Dimopoulos. 1994. The treatment of multiple myeloma. N. Engl. J. Med. 330:484-489.

26. Heslop, H. E., A. C. M. Bianchi, F. T. Cordingley, M. Turner, W. C. P. DeMel, A. V. Hoffbrand, and M. K. Brenner. 1990. Effects of interferon $\alpha$ on autocrine growth factor loops in B lymphoproliferative disorders. J. Exp. Med. 172:1729-1734.

27. Jernberg, H., M. Petterson, T. Kishimoto, and K. Nilsson. 1991. Heterogeneity in response to interleukin 6 (IL-6), expression of IL-6 and IL-6 receptor mRNA in a panel of established human multiple myeloma cell lines. Leukemia. 5:255-265.

28. Duperray, C., B. Klein, B. G. M. Durie, X. Zhang, M. Jourdaan, P. Poncelet, F. Favier, C. Vincent, J. Brochier, G. Lenoir, and R. Bataille. 1988. Phenotypic analysis of human myeloma cell lines. Blood. 73:566-572.

29. Schwab, G., C. B. Siegall, L. A. Aarden, L. M. Neckers, and R. P. Nordan. 1991. Characterization of an interleukin-6-mediated autocrine growth loop in the human multiple myeloma cell line, U266. Blood. 77:587-593.

30. Levy, Y., A. Tsapis, and J.-C. Brouet. 1991. Interleukin-6 antisense oligonucleotides inhibit the growth of human myeloma cell lines. J. Clin. Invest. 88:696-699. 
31. Yamasaki, K., T. Taga, Y. Hirata, H. Yawata, Y. Kawanishi, B. Seed, T. Taniguchi, T. Hirano, and T. Kishimoto. 1988. Cloning and expression of the human interleukin-6 (BSF-2/IFN $\beta 2$ ) receptor. Science (Wash. DC). 241:825828

32. Hibi, M., M. Murakami, M. Saito, T. Hirano, T. Taga, and T. Kishimoto. 1990. Molecular cloning and expression of an IL-6 signal transducer, gp130. Cell. 63:1149-1157.

33. Schwabe, M., J. Zhao, and H. F. Kung. 1994. Differential expression and ligand-induced modulation of the human interleukin-6 receptor on interleukin-6responsive cells. J. Biol. Chem. 269:7201-7209.

34. Lütticken, C., U. M. Wegenka, J. Yuan, J. Buschmann, C. Schindler, A. Ziemiecki, A. G. Harpur, A. F. Wilks, K. Yasukawa, T. Taga, et al. 1994. Transcription factor APRF and protein kinase JAK1 associate with the IL-6 signal transducer gp130. Science (Wash. DC). 263:89-92.

35. Stahl, N., T. G. Boulton, T. Farruggella, N. Y. Ip, S. Davis, B. A. Whitthuhn, F. W. Quelle, O. Silvennoinen, G. Barbieri, S. Pellegrini, et al. 1994. Association and activation of Jak-Tyk kinases by CNTF-LIF-OSM-IL-6 $\beta$ receptor components. Science (Wash. DC). 263:92-95

36. Brakenhoff, J. P. J., M. Hart, E. R. DeGroot, F. DiPadova, and L. A. Aarden. 1990. Structure-function analysis of human IL-6: epitope mapping of neutralizing monoclonal antibodies with amino- and carboxyl-terminal deletion mutants. J. Immunol. 145:561-568.

37. Hirata, Y., T. Taga, M. Hibi, N. Nakano, T. Hirano, and T. Kishimoto. 1989. Characterization of IL-6 receptor expression by monoclonal and polyclonal antibodies. J. Immunol. 143:2900-2906.

38. Nilsson, K., H. Bennich, S. G. O. Johansson, and J. Ponten. 1970. Established immunoglobulin producing myeloma (IgE) and lymphoblastoid (IgG) cell lines from an IgE myeloma patient. Clin. Exp. Immunol. 7:477-489.

39. Jernberg-Wiklund, H., M. Petterson, and K. Nilsson. 1990. Recombinant interferon- $\gamma$ inhibits the growth of IL-6-dependent human multiple myeloma cell lines in vitro. Eur. J. Haematol. 46:231-239.

40. Jernberg-Wiklund, H., M. Petterson, M. Carlsson, and K. Nilsson. 1992. Increase in interleukin 6 (IL-6) and IL-6 receptor expression in a human multiple myeloma cell line, U266, during long term in vitro culture and the development of a possible autocrine IL-6 loop. Leukemia 6:310-318.

41. Faltynek, C. R., and G. L. Princler. 1986. Modulation of interferon- $\alpha$ and interferon- $\gamma$ receptor expression during $\mathrm{T}$-lymphocyte activation and proliferation. J. Interferon Res. 6:639-653.

42. Anderson, K. C., R. M. Jones, C. Morimoto, and P. L. B. A. Barut. 1989. Response patterns of purified myeloma cells to hematopoietic growth factors. Blood. 73:1915-1924.

43. Splawsky, J. B., L. M. McAnally, and P. E. Lipsky. 1990. IL-2 dependence of the promotion of human B cell differentiation by IL-6 (BSF-2). J. Immunol. 144:562-569.
44. Herrmann, F., M. Andreeff, H.-J. Gruss, M. A. Brach, M. Lübbert, and R. Mertelsmann. 1991. Interleukin-4 inhibits growth of multiple myelomas by suppressing interleukin-6 expression. Blood. 78:2070-2074.

45. Sidell, N., T. Taga, T. Hirano, T. Kishimoto, and A. Saxon. 1991. Retinoic acid-induced growth inhibition of a human myeloma cell line via down-regulation of IL-6 receptors. J. Immunol. 146:3809-3814.

46. Taga, T., M. Narazaki, K. Yasukawa, T. Saito, D. Miki, M. Hamaguchi, S. D. M. Shoyab, G. D. Yancopoulos, and T. Kishimoto. 1992. Functional inhibition of hemopoietic and neurotrophic cytokines by blocking the interleukin 6 signal transducer gp130. Proc. Natl. Acad. Sci. USA. 89:10998-11001.

47. Jourdan, M., X. G. Zhang, M. Portier, J.-M. Boiron, R. Bataille, and B. Klein. 1991. IFN- $\alpha$ induces autocrine production of IL-6 in myeloma cell lines. J. Immunol. 147:4402-4407.

48. Nesbitt, J. E., and G. M. Fuller. 1992. Dynamics of interleukin-6 internalization and degradation in rat hepatocytes. J. Biol. Chem. 267:5739-5742.

49. Lasfar, A., J. Wietzerbin, and C. Billard. 1994. Differential regulation of interleukin- 6 receptors by interleukin- 6 and interferons in multiple myeloma cell lines. Eur. J. Immunol. 24:124-130.

50. Dunbar, C. E., T. M. Browder, J. S. Abrams, and A. W. Nienhuis. 1989 $\mathrm{COOH}$-terminal-modified interleukin-3 is retained intracellularly and stimulates autocrine growth. Science (Wash. DC). 2245:1493-1496.

51. Bauer, J., T. M. Bauer, T. Kalb, T. Taga, G. Lengyel, T. Hirano, T. Kishimoto, G. Acs, L. Mayer, and W. Gerok. 1989. Regulation of interleukin 6 receptor expression in human monocytes and monocyte-derived macrophages. $J$. Exp. Med. 170:1537-1549.

52. Nesbitt, J. E., and G. M. Fuller. 1992. Differential regulation of interleukin6 receptor and gp130 gene expression in rat hepatocytes. Mol. Biol. Cell. 3:103112.

53. Goldstein, J. L., R. G. W. Anderson, and M. S. Brown. 1979. Coated pits, coated vesicles, and receptor-mediated endocytosis. Nature (Lond.). 279:679685.

54. Mullberg, J., H. Schooltink, T. Stoyan, M. Gunther, L. Graeve, G. Buse, A. Mackiewicz, P. C. Heinrich, and S. Rose-John. 1993. The soluble interleukin6 receptor is generated by shedding. Eur. J. Immunol. 23:473-480.

55. Faltynek, C. R., G. L. Princler, G. L. Gusella, L. Varesio, and D. Radzioch. 1989. A functional protein kinase $C$ is required for induction of 2-5 A synthetase by recombinant interferon- $\alpha A$ in Daudi cells. J. Biol. Chem. 264:14305-14311.

56. Müller, M., J. Briscoe, C. Laxton, D. Guschin, A. Ziemiecki, O. Silennoinen, A. G. Harpur, G. Barbieri, B. A. Witthun, C. Schindler, et al. 1993. The protein tyrosine kinase JAK1 complements defects in interferon $\alpha / \beta$ and $-\gamma$ signal transduction. Nature (Lond.). 366:129-135.

57. Velazquez, L., M. Fellous, G. R. Stark, and S. Pellegrini. 1992. A protein tyrosine kinase in the interferon $\alpha / \beta$ signalling pathway. Cell. 70:311-322. 